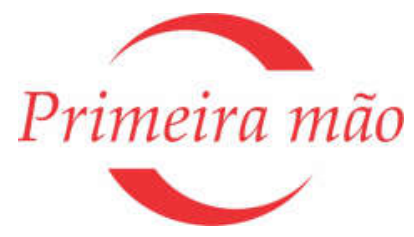

\title{
Construção visual de uma cidade moderna:
}
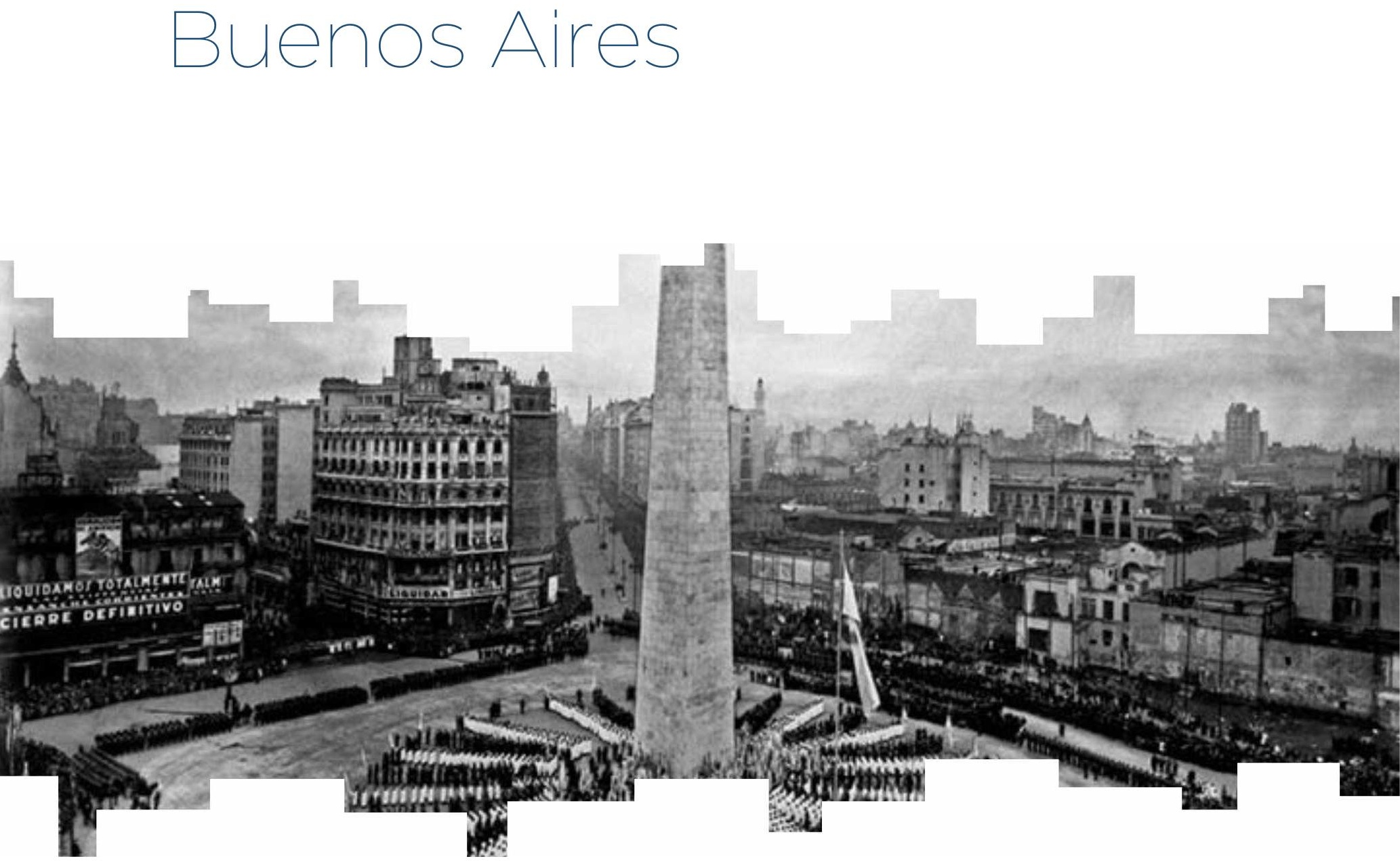

Praça da República, Festa da bandeira. Horacio Coppola, 1936, fotografia (detalhe).

\section{Annateresa Fabris}

Doutora em Artes pela Universidade de São Paulo (USP). Professora aposentada da Escola de Comunicações e Artes (ECA/USP). Autora, entre outros livros, de A fotografia e a crise da modernidade. São Paulo: Com-Arte, 2015.

annateresafabris@gmail.com

\section{Mariarosaria Fabris}

Doutora em Artes pela Universidade de São Paulo (USP). Professora aposentada da Faculdade de Filosofia, Letras e Ciências Humanas (FFLCH/USP). É autora, entre outros livros, de O neorealismo cinematográfico italiano: uma leitura. São Paulo: Edusp/Fapesp, 1996. piedcalv@gmail.com 
Construção visual de uma cidade moderna: Buenos Aires*

Visual construction of a modern city: Buenos Aires

Annateresa Fabris

Mariarosaria Fabris

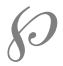

Um guindaste, em primeiro plano, simboliza a cidade em construção, onde presenças verticais mais modernas começam a despontar e a disputar o espaço com cúpulas e agulhas. Ao fundo, um horizonte infinito, cuja amplitude é ainda mais acentuada por uma massa de água, a qual, ao confundir-se com o céu, forma uma grande faixa luminosa.

Linhas verticais, constituídas por árvores, um poste de luz e chaminés, sublinham o aspecto geométrico de um conjunto de formas quase cúbicas que parecem sobrepor-se umas às outras num bairro indeterminado. A distância focal dá monumentalidade à volumetria retratada, diante da qual figuras humanas surgem diminutas.

Numa movimentada esquina de duas ruas centrais de uma metrópole, um dos símbolos da modernidade, um automóvel, ocupa um terço da foto com sua dianteira. Os luminosos verticais direcionam o olhar do observador para uma torre edificada ao fundo, conferindo profundidade de campo à imagem. $\mathrm{O}$ vestuário de mulheres e homens que cruzam a avenida corrobora a ideia de modernidade, assim como a fachada do grande magazine da esquina.

Uma sequência de pequenas lojas, que abrem suas portas para uma calçada tranquila e pouco povoada, leva a esquecer que a que está sendo focada é a mesma avenida, quilômetros acima, já distante do centro. As vitrines desse pequeno comércio não exibem signos modernos, mas simples objetos da vida cotidiana. Um dos letreiros apregoa a tradição dos préstimos da relojoaria. Dos transeuntes, um não está mal vestido; outro exibe seus trajes de trabalho ao empurrar o instrumento de onde tira seu sustento.

Num bulevar, a volumetria compacta dos prédios à esquerda contrasta com a elevação da massa escura das árvores à direita. Essa massa escura estabelece um contraponto com a luminosidade que predomina no fim da rua, fazendo convergir o olhar para a imponente cúpula do prédio, a quarta em ordem decrescente a aparecer na imagem.

Transeuntes apressados atravessam uma avenida: apesar de serem retratados em primeiro plano, o que acaba se impondo são os edifícios, apresentados não como uma massa compacta, mas enquanto objetos isolados. Assim,

\footnotetext{
* Escrito em colaboração com Mariarosaria Fabris em 2008 e revisto e ampliado em 2019, este texto corresponde ao primeiro capítulo do livro Realidade e ficção na fotografia latino-americana, de Annateresa Fabris, a ser publicado pela Editora da Universidade Federal do Rio Grande do Sul. Composto de um conjunto de artigos escritos entre 2008 e 2016, ele aborda duas questões nucleares na história da fotografia: a relação da imagem com o referente exterior e a possibilidade de criação de cenas e situações ficcionais. Tais questões são exemplificadas pela análise de realizações de Horacio Coppola, Facundo de Zuviría, Marcelo Brodsky, Gustavo Germano, Nicolás Guagnini, Lucila Quieto, Julio Pantoja, Juan Ángel Urruzola, Claudio Pérez, Grete Stern, Adriana Duque, Samy Sfoggia, Helena Martins-Costa, Tina Modotti e Fernando Lemos.
} 
o espectador passa a notar as alturas variadas dos prédios e sua atenção é atraída pelo moderno zigurate ${ }^{1}$ que se ergue para o céu.

É o olhar de Horacio Coppola a organizar e costurar os diferentes lugares de um único espaço urbano: a Buenos Aires dos anos 1920-1930.² Há um desenho lógico na captação desses aspectos variados da cidade, uma vez que todos eles remetem ao momento de virada na modernização da capital argentina.

Embora a "cidade de cúpulas e agulhas" 3 estivesse sendo contestada pela elite cultural local - que via, no ecletismo ${ }^{4}$ da modernização do final do século XIX, "a mistura caótica dos dialetos estrangeiros" e “o 'pomposo capricho' do parvenu imigrante, que alterou a 'ordenação hierárquica [da] sociedade [e] a fisionomia moral de seu povo'" 5 -, é logo esta cidade que ajuda a definir o perfil urbano novecentista com suas emergências verticais.

É o que se depreende, por exemplo, de um texto jornalístico e de fotografias do arquivo do jornal La Prensa: Diagonal Norte e Florida e O zepelim sobre Buenos Aires (Diagonal Norte e Florida), ambas do início dos anos 1930. No artigo de 21 de agosto de 1927, é exaltada a verticalização urbana, não apenas por meio de um conjunto de imagens, mas também com dizeres altamente significativos: "Cidade que cresce e se dilata incessantemente em direção aos quatro pontos cardeais, ou que se empina cada vez mais, como Buenos Aires, ultrapassando-se de um dia para o outro em seu afã de conquistar alturas, é cidade predestinada a ser chamada metrópole do mundo" ${ }^{6}{ }^{6}$

Captando-a a partir de suas diagonais Norte e Sul e destacando seu perfil urbano, o fotógrafo portenho também contribui, com suas tomadas, pa-

\footnotetext{
${ }^{1}$ Trata-se do Edifício Safico, projetado pelo engenheiro-arquiteto Walter Moll e construído entre 1932 e 1933. Situado na Avenida Corrientes, n. 456, representa, junto com os edifícios Comega (1931-1932) e Kavanagh, a incorporação do modelo do arranha-céu no panorama da cidade. O Safico é um típico representante do art déco pela silhueta da torre, que evoca os similares norte-americanos (além de remeter às construções maias) e pela "confortável suntuosidade" dos saguões de entrada e recepção, marcados pela confluência harmônica de mármores, espelhos, metal cromado, iluminação indireta e pelo mobiliário realizado pela Nordiska Kompaniet. Em algumas fotografias como Avenida Santa Fe. Praça San Martín (1936) e Paineira e bondes (1936), Coppola destaca a massa do Kavanagh, ao qual se tem acesso pela rua Florida, n. 1035/1055/1095 e pela praça San Martín, n. 1060/1094. Encomendado por Corina Kavanagh, que enviou a Nova York os arquitetos-engenheiros Gregorio Sánchez, Ernesto Lagos e Luis M. de la Torre para se inspirarem em seus maiores arranha-céus, o edifício é realizado entre 1933 e 1936. Durante muitos anos, foi não apenas o maior edifício de Buenos Aires, mas também o mais alto do mundo com sua estrutura de cimento armado. Embora racionalista, seu projeto é fundamentalmente eclético, com toques do estilo Tudor californiano, de art déco e de "românico". Cf. PETRINA, Alberto (org.). Guía del patrimonio cultural de Buenos Aires 8: arquitectura art déco. Buenos Aires: Gobierno de la Ciudad de Buenos Aires, 2007, p. 116-121; BÖHN, Mimi, GREMENTIERI, Fabio y VERSTROARTE, Xavier. Buenos Aires: art déco y racionalismo. Buenos Aires: Ediciones X. V., 2008, p. 209-213, e GUTIÉRREZ, Ramón. Arquitectura y urbanismo en Iberoamérica. Madrid: Cátedra, 1983, p. 598.

${ }^{2}$ As seis fotografias descritas são Perfil de Buenos Aires em direção ao Norte (1936), Sem título (1931), Rua Florida esquina com Corrientes (1936), Rua Corrientes (1931), Avenida de Maio, em direção ao Congresso (1936) e Corrientes esquina com Florida (s.d.), respectivamente.

${ }^{3}$ Apud WECHSLER, Diana. Buenos Aires (1920-1930): fotografía y pintura en la construcción de una identidad moderna. In: LOBETO, Claudio y WECHSLER, Diana (org.). Ciudades: estudios socioculturales sobre el espacio urbano. Madrid-Buenos Aires: Instituto Internacional del Desarrollo/Nuevos Tiempos, 1996, p. 30.

${ }^{4}$ A questão do ecletismo na arquitetura argentina é bastante complexa, por abarcar, entre outras, fontes italianas, francesas, germânicas, escandinavas, belgas, suíças, espanholas e britânicas. Cf. GREMENTIERI, Fabio. Ecleticism \& urbanity. In: Buenos Aires 1890-1925: ecleticism \& urbanity. Buenos Aires: Editarq, 1997, p. 5-16.

${ }^{5}$ GORELIK, Adrián. Das vanguardas a Brasília: cultura urbana e arquitetura na América Latina. Belo Horizonte: Editora UFMG, 2005, p. 83 e 88.

${ }^{6}$ Apud WECHSLER, Diana, op. cit., p. 29.
} 
ra esse imaginário que, frequentemente, traça paralelos entre Buenos Aires e os grandes emblemas norte-americanos, Chicago e Nova York. O fato de Coppola concentrar sua atenção em aspectos como automóveis, meios de transporte público, transeuntes, fachadas de edifícios, vitrines, luminosos ${ }^{7}$, cenas de vida noturna, nada mais faz do que evidenciar sua participação num projeto que pretende estabelecer uma identidade urbana moderna para a capital federal. Com efeito, em La Prensa, merecem igual destaque "a 'transformação edilícia de Buenos Aires' e a construção do Empire State Building de Nova York. Tomadas da Avenida Santa Fe e da Broadway sucedem-se com uma naturalidade que sugere a identificação das duas metrópoles dentro de um mesmo projeto: o da modernização" ${ }^{8}$

O ponto culminante dessa Buenos Aires vista como uma urbe americana talvez seja o documentário Assim nasceu o Obelisco, realizado por Coppola em 1936. Moderno totem, o obelisco da recém-aberta Avenida Nove de Julho é focalizado como um arranha-céu, graças ao uso frequente de plongées e contraplongées. A câmera não dá apenas a ver o aspecto exterior do marco comemorativo, a sombra que este projeta sobre a cidade (à guisa de um gigantesco relógio solar a marcar um novo tempo ${ }^{9}$ ), os modernos materiais empregados, mas penetra em seu interior, levando o espectador a subir até seu topo, junto com ela.

O caráter americano do monumento, inaugurado por ocasião das comemorações do quarto centenário de Buenos Aires, poderia ser inferido de outros índices: a edificação do obelisco em sessenta dias na confluência das avenidas Diagonal Norte, Corrientes e Nove de Julho, e sua localização em cima do túnel em que se cruzam as linhas B e C do metrô, a traduzirem concretamente as ideias de rapidez e fluxo constante. Projetado por um arquiteto moderno, Alberto Prebisch ${ }^{10}$ - que deixa sua assinatura em outras edificações

\footnotetext{
${ }^{7}$ Como lembram Jorge Francisco Liernur e Graciela Silvestri, aspectos da "identidade" de Buenos Aires vão sendo construídos em volta da iluminação das ruas, cujos primeiros ensaios datam de 1882 . Vitrines iluminadas, letreiros luminosos, monumentos sob refletores, edifícios emoldurados por pequenas lâmpadas, estruturas efêmeras e luxuosos lampiões conferem um novo ar à cidade. Graças à iluminação elétrica, os lugares adquirem hierarquias, que apagam, por algumas horas, a igualação do dia. A pobreza, a feiura, os defeitos e as irregularidades desaparecem, fazendo triunfar a ilusão "na atmosfera fantástica da luz". Essa percepção feérica é assim resumida por Ezequiel Martínez Estrada no ensaio La cabeza de Goliat (1940): "A hora de Buenos Aires é a tarde, a hora do deserto. [...] A noite, porém, é imensamente mais expressiva e profunda. [...] É então que Buenos Aires e todas as nossas cidades [...] adquirem seu sentido cósmico, sideral, telúrico. A luz estimula um tropismo de inseto fosforescente no habitante. Toda a população é atraída pelas iluminações públicas para as avenidas insones. [...] Quando a iluminação era feita com velas de sebo ou com gás a afluência era idêntica porque idêntica era a atração da luz. Ao contrário, as festas diurnas são melancólicas e frias". Cf. LIERNUR, Jorge F. y SILVESTRI, Graciela. El torbellino de la electrificación: Buenos Aires, 1880-1930. In: El umbral de la metrópolis: transformaciones técnicas y cultura en la modernización de Buenos Aires (1870-1930). Buenos Aires: Sudamericana, 1993, p. 26, 27 e 34.

${ }^{8}$ Apud WECHSLER, Diana, op. cit., p. 33.

${ }^{9}$ Cf. SASIAIN, Sonia. "Así nació el Obelisco": imágenes de una Buenos Aires moderna entre tradición y vanguardia. Nuevo Mundo, 8 out. 2019. Disponível em <https://journals.openedition.org/nuevomundo/ 77348>. Acesso em 28 dez. 2019.

${ }^{10}$ Leitor de L'Esprit Nouveau (revista dirigida por Le Corbusier e Amédée Ozenfant), Prebisch dirige, no começo da década de 1930, uma intensa campanha contra os cânones decorativos e em defesa de uma arquitetura geométrica e funcional. Nas páginas da revista Sur, galpões, hangares, silos, banheiras e mictórios são "ressemantizados em objetos de arte (num projeto que difere do ready made de Marcel Duchamp). São os mesmos silos tubulares, monumentais em sua geometria volumétrica, que aparecem na pintura dos anos vinte de Alfredo Guttero, também amigo de Coppola e fundamental na formação de seu olhar". Cf. SCHWARTZ, Jorge. Fundación de Buenos Aires: la mirada de Horacio Coppola. In: Horacio Coppola: fotografia. Madrid: Fundación Telefónica, 2008, p. 24.
} 
de formas geométricas e funcionais, opondo-se aos padrões decorativos anteriores -, sua construção fazia parte do plano de ressignificação urbanística empreendida pelo prefeito Mariano De Vedia y Mitre (1932-1938), o qual, em nome da modernização, bota abaixo vários pontos da cidade.

Em termos visuais, é importante ressaltar que Coppola não se limita a realizar o curta-metragem e a clicar o monumento de vários ângulos (Figura 1), mas estabelece um elo simbólico entre a nova cidade em construção e seus marcos de tradição, como fica patente em Praça de Maio (1936). Nessa imagem, focaliza o totem moderno ao fundo da Diagonal Norte, visto da praça, com seu jardim francês, a catedral neoclássica e os edifícios ecléticos, mas também com a Pirâmide de Maio, marco comemorativo da independência da Argentina, e o Cabildo, a lembrar a origem espanhola da nova nação. Dessa forma, o fotógrafo condensa, numa única tomada, várias etapas da história do país.

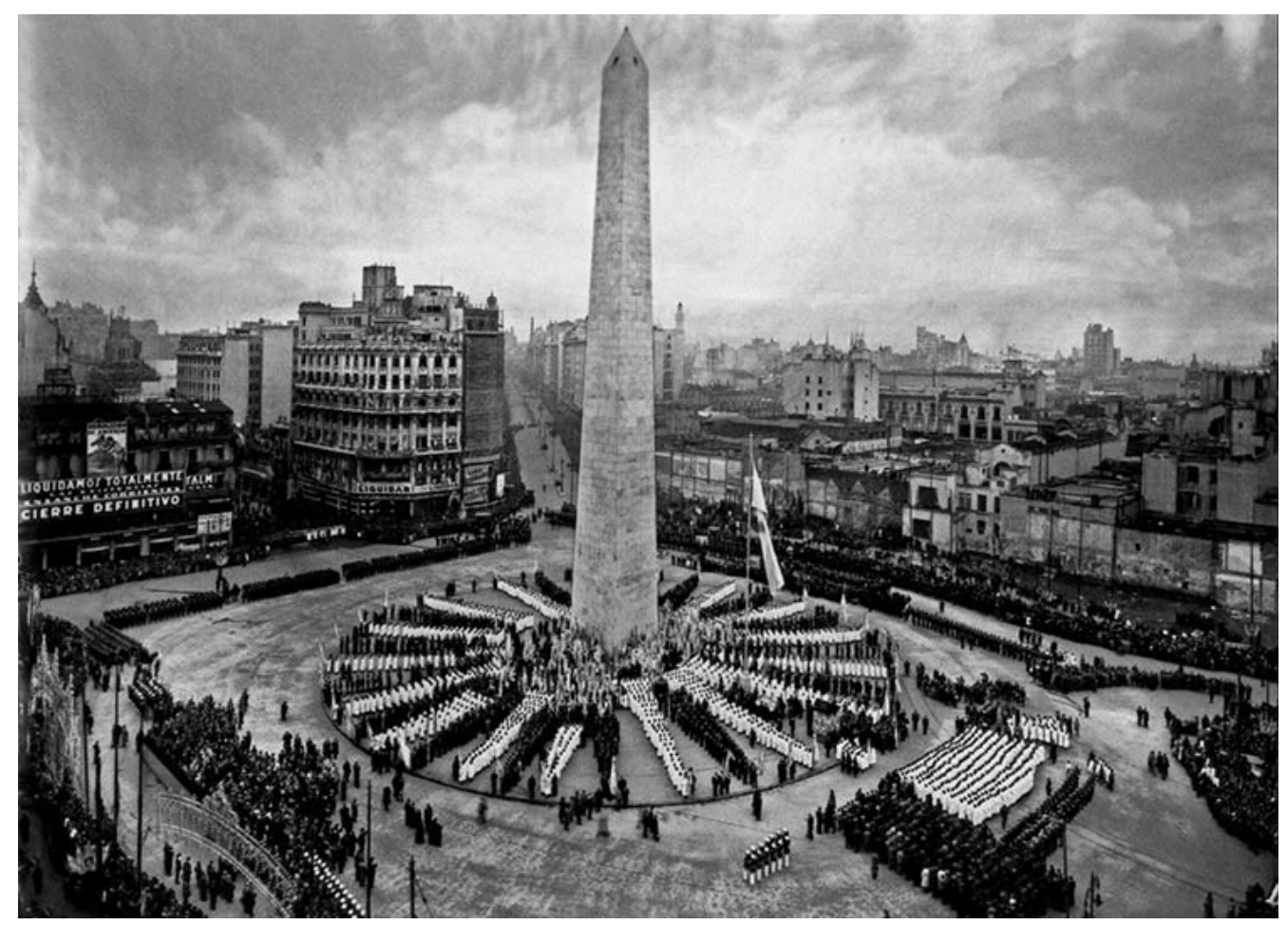

Figura 1. Praça da República, Festa da bandeira. Horacio Coppola, 1936.

A captação do elã vertical e a atenção aos aspectos da vida vertiginosa do centro têm uma complementaridade na focalização das áreas não centrais. Isso explica por que Coppola fotografa a Avenida Corrientes em diferentes pontos de sua extensão (a terceira e a quarta imagens aqui analisadas o atestam), mostrando como de esfuziante artéria principal passa a pacata via pública de bairro. A avenida central e a rua que leva à periferia, parecendo resistir às transformações, são efetivamente produtos da mesma modernização urbana. ${ }^{11}$

O bairro, para Coppola, tem diferentes facetas. Com suas lentes capta tanto aquele espaço que Jorge Luis Borges considera "mítico", por estar carre-

${ }^{11}$ Cf. SARLO, Beatriz. Modernidad y mezcla cultural. In: VÁZQUEZ-RIAL, Horacio (org.). Buenos Aires 1880-1930: la capital de un imperio imaginario. Madrid: Alianza, 1996, p. 188. 
gado de tradição, quanto os bairros do Sul, habitados por operários e imigrantes, como La Boca, que o atrai por seus cortiços, mas, principalmente, pela presença de outro símbolo moderno: o porto.

Nas antologias poéticas Fervor de Buenos Aires (1923), Luna de enfrente (1925) e Cuaderno San Martín (1929)12, como declara o próprio Borges: “Tenho comemorado em versos a cidade que me cinge / e os arrabaldes que se esgarçam". ${ }^{13}$ Ao deixar registrada a visão que tem de sua cidade, o poeta valoriza os bairros em cujas casas ressoa a voz dos antepassados:

O arrabalde é o reflexo de nosso tédio.

Meus passos claudicaram

quando iam pisar o horizonte

e fiquei entre as casas,

reticuladas em quadras

diferentes e iguais

como se fossem todas elas

monótonas lembranças repetidas

de uma única quadra.

O pastozinho precário,

desesperadamente esperançado,

salpicava as pedras da rua

e divisei em profundidade

os naipes de cores do poente

e senti Buenos Aires.

Esta cidade que pensei ser passado

é meu porvir, meu presente;

os anos que vivi na Europa são ilusórios,

eu sempre estive (e estarei) em Buenos Aires. ${ }^{14}$

Em 1921, quando regressa do estrangeiro, onde havia vivido durante sete anos, Borges não reencontra mais a Buenos Aires que havia guardado em sua memória:

Anúncios luminosos tironeando o cansaço

Charras algaraviadas

entram aos montes na quietude da alma

Cores impetuosas

Escalam as atônitas fachadas...

E eu as ruas cruzo desalmado

pela insolência das luzes falsas. ${ }^{15}$

\footnotetext{
${ }^{12}$ As poesias citadas neste texto (traduzidas por Mariarosaria Fabris) foram extraídas da edição de 1977 de Obra poética, em cujo prólogo, datado de 1969, Borges explica que fez algumas modificações nas antologias publicadas anteriormente. Por isso, quando necessário, recorreu-se a outra fonte, assinalando-a.

${ }^{13}$ BORGES, Jorge Luis. Casi juicio final [Luna de enfrente]. In: Obra poética 1923-1976. Buenos Aires: Emecé, 1977, p. 80.

${ }^{14}$ Idem, Arrabal [Fervor de Buenos Aires]. In: op. cit., p. 39.

${ }^{15}$ Idem, Ciudad [Fervor de Buenos Aires]. Apud GRAU, Cristina. Borges y la arquitectura. Madrid: Cátedra, 1989, p. 40. Confrontado com as "mudanças vertiginosas" pelas quais estava passando Buenos Aires desde a década de 1910, o poeta é obrigado a dar-se conta de que "a cidade da infância coincidia apenas em parte com a que se estava construindo". Por isso, engaja-se na tarefa de "recuperar, numa Buenos Aires transformada, a cidade de suas lembranças e igualmente recuperar essas lembranças diante de um modelo
} 
Hostil às transformações pelas quais, desde 1912, estava passado seu bairro, Palermo - como ele mesmo registrará, mais tarde, em Evaristo Carriego (1930) -, continua cantando o lugar mítico de sua infância:
À minha cidade de pátios côncavos como cântaros e de ruas que sulcam as léguas como um voo, à minha cidade de esquinas com auréola de ocaso e arrabaldes azuis, feitos de firmamento, à minha cidade que se abre clara como um pampa, eu voltei das velhas terras antigas do Ocidente e recobrei suas casas e a luz de suas casas e a tresnoitante luz dos armazéns [.... ${ }^{16}$

Para o escritor, Buenos Aires não é a cidade moderna, é antes "As encruzilhadas escuras/ que alanceiam quatro infinitas distâncias/ em arrabaldes de silêncio". ${ }^{17}$ É, portanto, o arrabalde, com "a mediania das casas,/ as modestas balaustradas e aldrabas"18, em que "as ruas recordam/ que foram campo um dia"19, com "o armazém" que "dominava a esquina" 20 , e onde as quadras podem resumir-se a uma única quadra, a de sua casa, circunscrita pelas ruas "Guatemala, Serrano, Paraguai, Gurruchaga". ${ }^{21}$

A palavra, no entanto, parece não conseguir dar conta sozinha dessa reconstrução do passado; por isso, ao lançar a biografia do poeta Evaristo Carriego, o autor não só anuncia que, em colaboração com Néstor Ibarra, publicará a "série fotográfica" Descubrimiento de Buenos Aires"22, como ilustra o livro de 1930 com duas fotos de Horacio Coppola. Essa tarefa de recuperar a cidade de sua infância evidencia-se, ainda, em alguns ensaios editados entre 1925 e 1928: Inquisiciones, El tamaño de mi esperanza e El idioma de los argentinos. ${ }^{23} \mathrm{~A}$ "grande aldeia" da virada do século XIX para o XX, a mesma cantada em versos por Carriego, de "casas baixas de taipas rosadas", ao passar por uma série sucessiva de planos de sistematização, principalmente da segunda metade dos anos 1910 em diante, estava sendo substituída pela urbe moderna, com seus "edifícios cujas fachadas tapavam o céu". ${ }^{24}$

\footnotetext{
em transformação". Disso resulta a nostalgia de Fervor de Buenos Aires, cujos poemas têm como objetivo "recordar a Buenos Aires esquecida no momento em que esta começa a desaparecer materialmente". Cf. SARLO, Beatriz. Jorge Luis Borges, um escritor na periferia. São Paulo: Iluminuras, 2008, p. 27 e 28.

${ }^{16}$ BORGES, Jorge Luis. Versos de catorce [Luna de enfrente]. In: op. cit., p. 83.

${ }_{17}$ Idem. Cercanías [Fervor de Buenos Aires]. In: op. cit., p. 54.

${ }^{18}$ Idem. Calle desconocida [Fervor de Buenos Aires]. In: op. cit., p. 26.

${ }^{19}$ Idem. La noche de San Juan [Fervor de Buenos Aires]. In: op. cit., p. 53.

${ }^{20}$ Idem. Curso de los recuerdos [Cuaderno San Martín]. In: op. cit., p. 94.

${ }^{21}$ Idem. Fundación mítica de Buenos Aires [Cuaderno San Martín]. In: op. cit., p. 90. Em homenagem a Jorge Luis Borges, o trecho da Rua Serrano, em que se localizava a casa em que ele morou, hoje leva seu nome.

${ }^{22} \mathrm{O}$ projeto, no entanto, não se realizou.

${ }^{23}$ Parece haver um perfeito espelhamento entre os textos poéticos e os ensaísticos, pois Borges expressa as mesmas ideias com termos idênticos, como no trecho a seguir, extraído de Inquisiciones (1925): "Buenos Aires não é uma cidade elevada e ascendente [...]. É de fato uma cópia da planície que a cinge, cuja retidão rendida tem continuação na retidão de ruas e casas. As linhas horizontais vencem as verticais. As perspectivas - de moradias de um ou dois andares, enfileiradas e confrontando-se ao longo das léguas de asfalto e pedra - são demasiado fáceis para não parecer inverossímeis. Quatro infinitos atravessam cada encruzilhada". Cf. GORELIK, Adríán, op. cit., p. 81.

${ }^{24}$ Cf. GRAU, Cristina, op. cit., p. 19 e 20; GREMENTIERI, Fabio, op. cit., p. 13 e 14; BERJMAN, Sonia. Plazas y parques de Buenos Aires: la obra de los paisajistas franceses 1860-1930. Buenos Aires: Fondo de Cultura Económica, 1998, p. 17.
} 
Projetando-se em seu antecessor, Borges - a partir de um lugar literário, inventado, a margem ${ }^{25}$, a meio caminho entre o mundo rural e o urbano torna presente o passado, juntando a renovação estética com o saudosismo da memória: “O bairro converte-se em margem, orla da planície; o vazio é a inclusão do pampa no traçado urbano incompleto; a cor das taipas rosadas cita a cor rural das esquinas do campo". ${ }^{26}$

O tom nostálgico que permeia os poemas de Borges, bem como Evaristo Carriego ${ }^{27}$, é fruto de "um ideologema novo construído a partir dos restos de uma Buenos Aires conjeturada nas recordações da infância"28: "Esta é uma elegia/ de um Palermo traçado no vaivém da lembrança/ e que vai embora na pequena morte do olvido". ${ }^{29}$ Pode-se perceber um sentimento semelhante nas fotografias de Coppola, que, no final dos anos 1920, acompanha o escritor em seus passeios ao longo do córrego Maldonado? ${ }^{30}$

Esses passeios sem rumo certo, que começavam na avenida Corrientes, na altura do bairro Once e prosseguiam até o cemitério de Chacarita, despertam lembranças diferentes nos dois companheiros. Enquanto Coppola afirma que o interesse de ambos residia na cidade vista como "uma paisagem", Borges evoca aquele momento por meio de um poema nostálgico:

\author{
O que foi feito daqueles \\ dois rapazes \\ que lá por mil, novecentos e vinte e tantos \\ buscavam com ingênua fé platônica \\ pelas longas calçadas da noite \\ do Sul ou na guitarra de Paredes \\ ou nas fábulas de esquinas e de facas \\ ou na aurora, que não tocou ninguém, \\ a secreta cidade de Buenos Aires? ${ }^{31}$
}

\footnotetext{
${ }^{25}$ Sarlo esclarece que o termo orilla é trabalhado por Borges em seus diversos significados - margem, fio, limite, costa, praia - de 1920 até o final de sua trajetória literária. Espelho infiel da cidade moderna destituída de qualidades estéticas e metafísicas, a margem designava os bairros distantes e pobres, habitados frequentemente por trabalhadores dos matadouros e frigoríficos, de linhagem hispano-criolla e, logo, anteriores à imigração. Discretos e taciturnos, os orilleros de Borges são "sobreviventes das últimas décadas do século XIX nas primeiras do XX. A verdade poética das orillas se constrói em leve anacronismo. Esse deslocamento temporal é invenção de Borges". Cf. SARLO, Beatriz. Jorge Luis Borges, um escritor na periferia, op. cit., p. 47-49.

${ }_{26}$ SARLO, Beatriz. Una modernidad periférica: Buenos Aires 1920 y 1930. Buenos Aires: Nueva Visión, 1988, p. 47. ${ }^{27}$ O livro é analisado por idem, Jorge Luis Borges, um escritor na periferia, op. cit., p. 51-57.

${ }^{28}$ Idem, Una modernidad periférica: Buenos Aires 1920 y 1930, op. cit., p. 47.

${ }^{29}$ BORGES, Jorge Luis. Elegia de los portones [Cuaderno de San Martín]. In: op. cit., p. 91.

${ }^{30}$ A "ribeira hostil do Maldonado", cantada na "Elegia de los portones", desapareceu com a canalização do córrego, como lembra o autor num poema de 1965: “Lá pelo Maldonado, / Que hoje corre cego, / Lá pelo bairro cinzento / Que cantou o pobre Carriego [...]". Com um curso de aproximadamente vinte quilômetros, o arroio Maldonado atravessava dez bairros da cidade (entre os quais Liniers, Vélez Sarsfield, Caballito, Villa Crespo e Palermo) antes de desembocar no rio da Prata. Enterrado em 1929, foi canalizado sete anos mais tarde. Cf. BORGES, Jorge Luis. Elegía de los portones [Cuaderno de San Martín] e Un cuchillo en el Norte [Para las seis cuerdas]. In: op. cit., p. 92 e 291, e Secreta Buenos Aires. La leyenda del Maldonado. Clarín, Buenos Aires, 12 mar. 2012. Disponível em <https://www.clarin.com/ciudades/leyenda-arroyomaldonado_0_HJdriDL2w7l.html>. Acesso em 28 dez. 2019.

${ }^{31}$ Apud KNIGHT, Andrea. Horacio Coppola sigue siendo testigo de la ciudad. La Nación, Buenos Aires, 17 dez. 2000, Suplemento Lifestyle. Disponível em <https://www.lanacion.com.ar/lifestyle/horacio-coppolasigue-siendo-testigo-de-la-ciudad-nid213038>. Acesso em 8 out. 2009.
} 
Adrián Gorelik, discordando da leitura em chave nostálgica da relação de Borges com o subúrbio, por acreditar que este encontra, em seu próprio presente suburbano, "o espaço para combinar, de modo tipicamente vanguardista, a tradição e a novidade" 32 , afirma que as imagens do fotógrafo ratificam a operação poética, porque "compartilham o mesmo olhar que o estava produzindo como representação mitológica". ${ }^{33}$ De acordo com o autor, Coppola lança sobre a cidade existente o mesmo "olhar-manifesto" construído pela vanguarda literária e artística, a qual, na falta de uma arquitetura nova, recorta e seleciona, no tecido existente, "seus fragmentos ideais". As casinhas do subúrbio são clicadas pelo fotógrafo como se fossem "objetos do desenho de vanguarda". Transformadas em volumes essenciais e abstratizantes, proclamam uma pureza modernista que dá continuidade à vontade de ordenar o "caos eclético" da cidade, perseguida pela elite bonaerense desde o começo do século XX. ${ }^{34}$ Duas iniciativas nesse sentido são destacadas por Sarlo. A ficção arquitetônica (1927-1935) de Wladimiro Acosta pretendia, por meio do cityblock, propor uma alternativa ao crescimento caótico da cidade. $\mathrm{O}$ arquiteto imagina diversas ações coordenadas: atribui lugares à rede de transportes, à produção, ao ócio e ao comércio; ilumina a cidade; organiza idealmente a expansão urbana ao longo de cinturões edificados e pistas expressas que margeiam o verde, inexistente na cidade real. Victoria Ocampo, por sua vez, a partir da plataforma da revista Sur, fundada em fins de 1930, torna-se patrocinadora e mecenas do modernismo arquitetônico, concebido como um programa de homogeneização e purificação do gosto, ao qual caberia opor-se ao caos tipológico atribuído à imigração. Seus volumes e fachadas brancas deveriam disciplinar a rua e impedir "a materialização construtiva dos sonhos vulgares do parvenu enriquecido". 35

Essa vontade de ordenação, que Gorelik faz coincidir com uma opção pelo classicismo, é por ele localizada também nas imagens que Coppola registra para o álbum Buenos Aires 1936. Nessa coletânea, organizada para celebrar o quarto centenário da cidade, o fotógrafo representaria "os setores mais modernos da cidade como se o tempo não passasse por eles". Seria o caso da Di-

\footnotetext{
${ }^{32}$ Embora o autor empregue o termo "vanguardista", seria mais adequado falar em "modo tipicamente moderno", dado que a vanguarda mantém uma relação conflituosa com a tradição.

${ }^{33}$ Borges, talvez, recusaria o adjetivo "mitológico". Ao referir-se à poesia que abre Cuaderno San Martín, no prólogo da antologia, redigido em 1969, declara: "Diante da indignação da crítica, que não perdoa se um autor se arrepende, escrevo agora Fundação mítica de Buenos Aires e não Fundação mitológica, já que a última palavra sugere maciças divindades de mármore". Cf. BORGES, Jorge Luis, op. cit., p. 87.

${ }^{34}$ Cf. GORELIK, Adrián, op. cit., p. 76 e 77.

${ }^{35}$ SARLO, Beatriz. Jorge Luis Borges, um escritor na periferia, op. cit., p. 33 e 34. Paradoxalmente, Ocampo encomenda o projeto de sua casa modernista ao arquiteto Alejandro Bustillo, especializado no estilo neoclássico francês. Predominante no bairro de Palermo Chico, em que a residência será construída (rua Rufino de Elizalde, n. 2831), esse estilo contrasta fortemente com a casa de "linhas puras e lógicas" ( $L a$ Nación, 4 de agosto de 1929), provocando protestos dos vizinhos. Bustillo deixa de lado um projeto de Le Corbusier para outro terreno (1928) e concebe uma estrutura sóbria, de linhas puras e despojadas de qualquer ornamento. O interior denuncia a manutenção de alguns princípios acadêmicos, sobretudo na definição dos espaços, demasiado segmentados para uma construção moderna. Essa solução de compromisso não deixa de ter certo parentesco com a casa modernista de São Paulo, localizada na rua Santa Cruz (1927-1928), na qual Gregori Warchavchik, por força das circunstâncias, limita as inovações ao plano estético e faz algumas concessões à tradição local (varanda da face posterior). Cf. ARIAS INCOLLÁ, Nani (org.). Guia del patrimonio cultural de Buenos Aires: arquitectura moderna. Buenos Aires: Gobierno de la Ciudad de Buenos Aires, 2006, p. 20 e 21; Casa Victoria Ocampo: de la provocación arquitectónica a sede de las artes. Disponível em <https://fnartes.gob.ar/casa-victoria-ocampo/historia>. Acesso em $30 \mathrm{dez}$. 2019, e BRUAND, Yves. Arquitetura contemporânea no Brasil. São Paulo: Perspectiva, 1981, p. 65-67.
} 
agonal Norte, dos altos edifícios da ampliada Avenida Corrientes, apresentados como "brancas moles maciças sem tempo", e não em ângulos expressionistas; dos silos do porto, mostrados numa imagem aplainada e numa composição clássica. ${ }^{36}$

A atemporalidade defendida pelo autor pode ser problematizada por uma análise das obras. No caso da fotografia da Diagonal Norte, há inequívocos signos temporais nos letreiros que pontuam o edifício em primeiro plano, com suas cumeeiras a lembrar um navio, e nos diversos posicionamentos dos veículos ao longo da avenida, que apontam para o fluxo dinâmico do trânsito. Nas tomadas da Avenida Corrientes, o isolamento conferido ao único arranha-céu tem um objetivo evidente: acentuar seu aspecto monumental e funcional, convertendo-o em símbolo da cidade projetiva, em construção. Em Noturno, rua Corrientes (1936), o arranha-céu enlaça-se com o Obelisco, graças a um jogo cromático que opõe a massa escura do edifício pontilhada de luzes ao aspecto diáfano do monumento iluminado (Figura 2). As imagens do porto respondem a vários partidos compositivos, em que pese a presença de um elemento unificador: a ênfase dada à verticalidade de chaminés, silos e mastros.

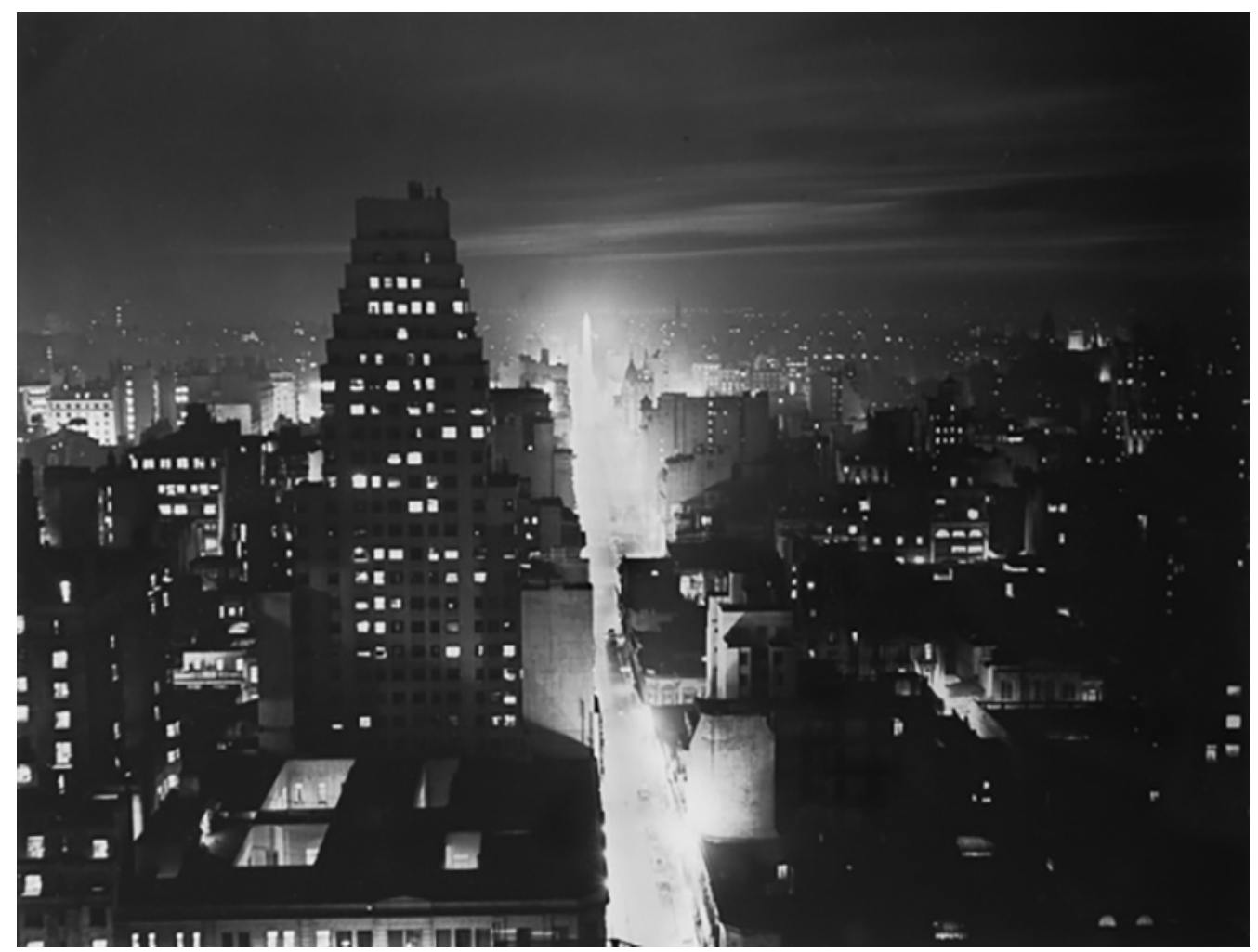

Figura 2. Noturno, rua Corrientes, de Reconquista até Praça da República. Horacio Coppola, 1936.

E, retomando a parceria do fotógrafo com Borges, algumas outras considerações fazem-se necessárias, uma vez que, em sua interpretação, Gorelik, além de não levar em conta a relação bem mais complexa que Coppola estabelece com a cidade como um todo, se concentra num único aspecto da visão que este teria do bairro. Se das incursões do escritor e do fotógrafo pelos arra-

${ }^{36}$ Cf. GORELIK, Adrián, op. cit., p. 91. 
baldes resultaram as duas ilustrações de Evaristo Carriego, testemunhando um interesse compartilhado, não parece que Borges seja a única figura determinante na valorização que Coppola faz desse aspecto da capital argentina. Como o próprio autor assinala, outro encontro decisivo foi o com Le Corbusier, quando este visitou Buenos Aires, uma das etapas da viagem de 1929 à América do Sul. ${ }^{37} \mathrm{O}$ arquiteto suíço não tem uma visão muito positiva de Buenos Aires..$^{38}$ Apresentada como uma "cidade gigantesca, a mais inumana que se possa imaginar" no "Prólogo americano"39 (10 de dezembro de 1929), a fisionomia de Buenos Aires é analisada na primeira conferência, proferida na Associação Amigos da Arte ${ }^{40}$ em 3 de outubro. Capital meridional do novo mundo, Buenos Aires é definida como

uma cidade que está no erro, no paradoxo, uma cidade que não possui espírito novo, nem espirito antigo, mas simples e unicamente, uma cidade de 1870 a 1929, cuja forma atual será passageira, cuja estrutura é indefensável, desculpável, mas insustentável, insustentável como todos esses imensos bairros de cidades nascidas na Europa sob o signo de uma súbita expansão industrial nos fins do século XIX, mas lamentável confusão de fins e meios.

Inconformado com o desprezo exibido por Buenos Aires em relação às três bases da arquitetura e do urbanismo - o mar e o grande porto, a vegetação magnífica do parque de Palermo e o céu ${ }^{41}-$, Le Corbusier propõe uma solução para retirá-la da condição de "cidade amorfa", incapaz de aproveitar o potencial de energia e a pujança proporcionados pela natureza. Na nona conferência (Amigos da Arte, 18 de outubro), propõe a construção de uma imensa plataforma de cimento armado sobre pilotis no rio da Prata, que abriria a cidade para o mar e para o céu, subtraindo-a de seu mal maior: a "neurastenia". ${ }^{42}$

Essa visão negativa não impede que o arquiteto detecte uma presença realmente moderna na arquitetura da cidade, como ele explicita na oitava

\footnotetext{
${ }^{37}$ Cf. idem, ibidem, p. 78. Se Coppola considera que as conferências de Le Corbusier foram a "base" de suas "futuras fotografias", não se pode esquecer que, nesse período, ele passa a interessar-se por cinema, a ponto de presidir o primeiro cineclube de Buenos Aires (1929). A busca de uma nova visualidade consolida-se no início da década de 1930, quando Coppola estuda fotografia na Bauhaus, com Walter Peterhans, produzindo algumas imagens eivadas de estranhamento. Cf. COPPOLA, Horacio. Texto autobiográfico. In: Horacio Coppola: fotografia, op. cit., p. 321, e COKE, Van Deren. Avanguardia fotografica in Germania, 19191939. Milano: Il Saggiatore, 1982, p. 31.

${ }^{38}$ A convite da Faculdade de Ciências Exatas (que englobava as Escolas de Arquitetura, de Engenharia e de Ciências) e da Associação Amigos da Arte, cuja sede era a Galeria Van Riel, localizada na rua Florida, n. 659, Le Corbusier profere dez conferências em Buenos Aires, entre 3 e 19 de outubro. Cf. Le Corbusier en Buenos Aires. Buenos Aires: Sociedad Central de Arquitectos, 1979, p. 9.

${ }^{39} \mathrm{O}$ prólogo e as conferências foram publicados no livro Précisions sur un état present de l'architecture et de l'urbanisme (1930). Ele é apresentado por Prebisch no n. 1 da revista Sur (dez. 1930-mar. 1931). No n. 12 (set. 1935), a revista publica o artigo "El espiritu de Sudamérica", em que o arquiteto reforça sua diatribe contra Buenos Aires: "não existe cidade mais inumana [...] chamei-a 'a cidade sem esperança'. Não há montanha, nem colina, nem árvore, nem mar, nem céu nesse apertado coração da cidade. O pampa argentino está mais para lá; não se vê o Rio da Prata [...]". Cf. MICELI, Sergio. Sonhos da periferia: inteligência argentina e mecenato privado. São Paulo: Todavia, 2018, p. 137, n. 19.

${ }^{40}$ Fundada em 1924 com o objetivo de apoiar os artistas locais e proporcionar o contato da sociedade com diversas produções artísticas nacionais e internacionais, a Associação Amigos da Arte desenvolve um vasto programa de atividades nas áreas das artes visuais, música, literatura e teatro, além de promover conferências e publicações.

${ }^{41}$ Cf. Le Corbusier en Buenos Aires, op. cit., p. 19 e 20.

${ }^{42}$ Idem, ibidem, p. 51-53.
} 
conferência (Faculdade de Ciências Exatas, 17 de outubro). Incomodado com a exaltação dos "pequenos bairros e cottages ingleses", que produzem nele "o efeito de uma bofetada", o arquiteto propõe um jogo perceptivo a seus ouvintes:

Dizem: "não temos nada, nossa cidade é muito nova". [...] Vejam: desenho um muro de fechamento, abro uma porta nele, o muro se prolonga pelo telhado triangular à esquerda de um beiral com uma pequena janela no meio; à esquerda desenho uma galeria bem quadrada e nítida. Sobre o terraço da casa elevo esse delicioso cilindro: a caixa d'água. Vocês pensam: "Puxa, eis o que faz uma cidade moderna!" Nada disso: estou desenhando as casas de Buenos Aires. [...] Foram feitas e são feitas todos os dias pelos empreiteiros italianos. São uma expressão muito lógica da vida de Buenos Aires. Suas dimensões são justas, suas formas, harmoniosas, suas respectivas localizações foram encontradas de maneira habilidosa. É o folclore de vocês; há cinquenta anos e, no entanto, ainda hoje, me dizem: "Não temos nada!!!". Respondo-lhes: têm isso, uma planta padrão e o jogo de formas feitas sob a luminosidade argentina, um jogo de formas muito belas, muito puras. [...] Vocês fizeram nascer com naturalidade o terraço-jardim na Argentina...". 43

As estruturas geométricas que Le Corbusier detecta nas casas suburbanas estão presentes nas fotografias de Coppola. Basta deter-se em Rua Paraguai, Palermo e Rua Jean Jaurés esquina com Paraguai, ambas de 1929 - que, ao integrarem a primeira edição de Evaristo Carriego, foram intituladas Casas de bairro em Buenos Aires. Jaurés (antes Bermejo), número 1.000 e Esquina nas antigas margens. Rua Paraguai, número 2.600, respectivamente ${ }^{44}$ - para perceber que a visão do fotógrafo não é a mesma do escritor. Na primeira, o que chama a atenção é a sobreposição de planos e formas simples, como os descritos na conferência; na outra, é o destaque dado ao ângulo reto formado pela confluência das duas esquinas. Além da segunda imagem descrita no início desse texto, vêm corroborar essa ideia obras como Muros (1931), com o entrecruzarse de linhas retas e oblíquas e o escalonamento de planos, e Bairro de Palermo (1936), em que o olhar é conduzido para o fundo da composição pelo ângulo agudo formado pelas linhas oblíquas, associadas ao jogo volumétrico entre claros e escuros.

Esse jogo de linhas e formas geométricas, embora ainda presente nas imagens dedicadas ao porto e seus arredores ${ }^{45}$, é atenuado por um registro

\footnotetext{
${ }^{43}$ Idem, ibidem, p. 49. O olhar que Le Corbusier lança sobre Buenos Aires não é apenas fruto do impacto provocado por sua visão direta. O pintor Alfredo González Garaño, seu contato em Paris e factótum da visita, apresenta-o ao núcleo criollista da elite social e intelectual argentina, levando o arquiteto a sintonizar suas propostas urbanísticas com aspectos essenciais do relato mítico sobre a cidade elaborado por esse grupo. Essa sintonia seria evidenciada na proposta da Cidade dos negócios - a plataforma de arranha-céus que permitiria recuperar o rio e o velho coração da cidade - e na exaltação da "luminosidade argentina", núcleo central da qualidade pampeana celebrada pelos modernos criollistas. Cf. GORELIK, Adrián. Horacio Coppola, 1929. Borges, Le Corbusier y las casitas de Buenos Aires. In: Horacio Coppola: fotografia, op. cit., p. 55 e 56.

${ }^{44}$ BORGES, Jorge Luis. Evaristo Carriego. Buenos Aires: M. Gleizer, 1930, depois das p. 47 e 64 respectivamente.

${ }^{45}$ A questão do porto não pode ser dissociada da relação da cidade com o rio. Trata-se de uma relação conflituosa entre "natural" e "artificial", em virtude da presença de um ambiente que carecia das marcas culturais da natureza europeia. Iniciadas em 1875, com a dragagem do Riachuelo, as obras têm um novo marco em 1886, quando é aprovado o projeto definitivo para Porto Madero. Enquanto o Riachuelo tinha uma importância local e para a navegação fluvial, Porto Madero era o porto ultramarino, além de estar ligado ao desenvolvimento ferroviário. Cf. SILVESTRI, Graciela. La ciudad y el río: un estudio de las
} 
mais realista na captação de uma zona da cidade que se constrói com os dejetos da modernidade e das condições de vida de seus habitantes, como em $\mathrm{La}$ Boca (1931) e Favela, Riachuelo (1936). ${ }^{46}$ No momento em que se volta para esse espaço, não estará o fotógrafo mais próximo da construção de outra margem levada a cabo por novos protagonistas do campo intelectual, principalmente literário, ou seja, pelos que provinham desse mesmo espaço marginal (por sua origem imigrante) e o transformavam em tema de suas obras?

O espaço que abriga as figuras da marginalidade é também o espaço do crescimento e da pujança da cidade. Na imprensa do período, assim como nas fotos de Coppola, o porto é um elemento determinante da fisionomia de Buenos Aires. Navios, barcos, rebocadores, chatas, guindastes e a Ponte Almirante Brown (Figura 3) compõem o cenário do que foi definido como a metáfora da cidade-porto, que esvaziava como "uma voraz máquina centrípeta, o restante de um país que não se via como urbano, quando já começava a sê-lo quase totalmente". ${ }^{47}$

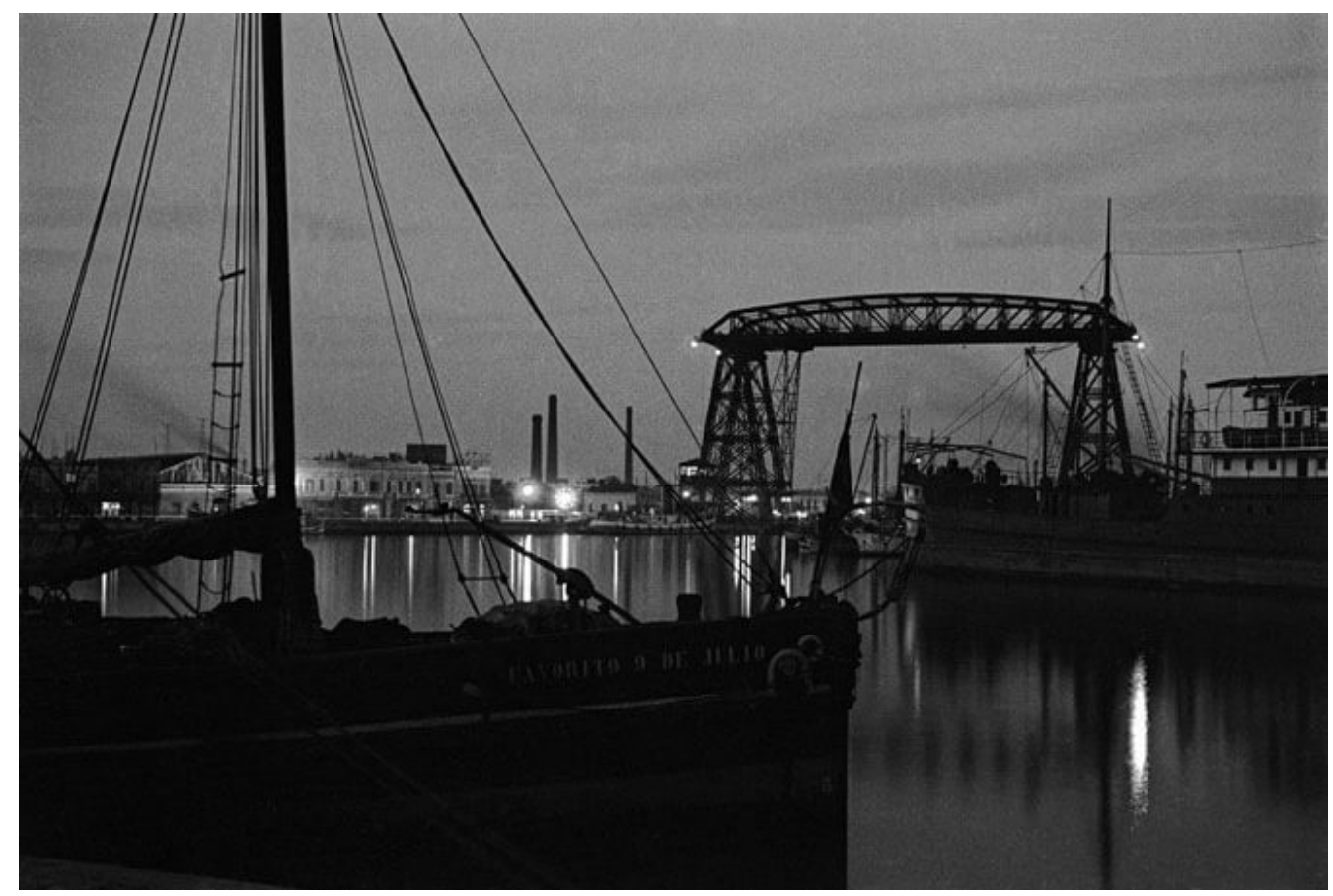

Figura 3. Riachuelo, Ponte Almirante Brown. Horacio Coppola, 1931.

Ao contrário do escritor, que concentra sua deambulação poética nos bairros do Norte e do Oeste (Palermo, Saavedra, Boedo), Coppola abarca com seu olhar uma cidade muito mais variegada. La Boca, com suas casas operárias e a zona portuária, o centro metropolitano, as presenças ecléticas, o subúrbio borgiano fazem parte de uma única malha urbana, exibida em suas

relaciones entre técnica y naturaleza a través del caso del puerto de Buenos Aires. In: LIERNUR, Jorge F. y SILVESTRI, Gabriela, op. cit., p. 98, 99 e 133.

${ }^{46}$ Em fins do século XIX, com a definição do perímetro da cidade (1887), a administração privilegia o setor norte e as orlas fluviais da cidade, condenando a zona sul a um processo de "tugurização". Em 1892, existiam 2.200 cortiços, dotados de 31.000 cômodos, habitados por 121.000 pessoas (4 habitantes por quarto). Cf. GUTIÉRREZ, Ramón, op. cit., p. 531.

${ }^{47}$ SARLO, Beatriz. Modernidad y mezcla cultural, op. cit., p. 184. 
descontinuidades e contrastes. A cidade construída por suas lentes não é um lugar ideal. É um espaço de tensões, conflitos, misturas, um espaço por excelência heterogêneo, profundamente transformado pelo capitalismo em seus diferentes aspectos.

Nessa cidade em constante transformação, que se via como uma metrópole do mundo, Coppola não capta apenas seus aspectos mais ostensivos a pujança do porto, a urbe vertical - ou o subúrbio geometrizado, mas, também, a outra face da modernização, representada pelas habitações da zona portuária. Nesta, guindaste e chaminé tomam o lugar de cúpula, agulha, arranha-céu, remetendo para um espaço dual - um espaço em expansão e um espaço de exclusão -, no qual não há praticamente presenças humanas.

Se uma das questões centrais da cultura argentina das primeiras décadas do século XX é a configuração de um "começo" 48 , é a busca de uma identidade diante da presença cada vez mais evidente do imigrante (inclusive nos campos da cultura e da arte), a Buenos Aires de Coppola pode ser inscrita numa outra dimensão, a do tecido urbano compósito, uma vez que não é improvável que ele a tenha focalizado em seus diversos aspectos exatamente por ser de origem imigrante.

Com o "mito de Ícaro", o fotógrafo insere a urbe portenha no lugar utópico denominado universal city ${ }^{49}$, com suas edificações verticais e, sobretudo, com suas cúpulas e agulhas; já com a visão ao rés-do-chão, o que se impõe é a heterogeneidade, é a fragmentação, é o passado convivendo com o presente, é um processo de mudança, no qual os atores sociais ocupam diferentes espaços e desempenham diferentes papéis. A Buenos Aires multifacetada de Coppola não é a "grande aldeia" de Borges, que não existe maisso; é antes um espaço no qual se entrecruzam as muitas temporalidades que compõem a cena urbana, um espaço no qual o aporte do imigrante não pode deixar de ser notado, tanto em seus aspectos mais vistosos (ecletismo e presença no comércio da cidade), quanto naquela margem enfeixada em La Boca, com suas cenas silentes de exclusão.

Texto recebido em 18 de julho de 2021. Aprovado em 8 de agosto de 2021.

\footnotetext{
48 SARLO, Beatriz. Una modernidad periférica: Buenos Aires 1920 y 1930, op. cit., p. 45.

${ }^{49}$ Ver MARCHÁN FIZ, Simón. Contaminaciones figurativas: imágenes de la arquitectura y la ciudad como figuras de lo moderno. Madrid: Alianza, 1986, p. 144.

${ }^{50}$ Afinal, o poeta havia escrito: "Eu sou o único espectador desta rua; / se deixasse de vê-la, ela morreria". BORGES, Jorge Luis. Caminata [Fervor de Buenos Aires]. In: op. cit., p. 52.
} 